\title{
Tradução do Fragmento do livro Sepultura de Fabián Severo
}

\author{
George Hamilton Pellegrini FERREIRA*
}

Escute este gotejar de pássaro. Essa música de cá-cá-cá, pié-pié-pié, iá-iá-iá. Eu gosto de me levantar cedo, preparar o chimarrão, me sentar neste canto para escutar a canção dos pássaros que esticam a manhã.

Esta pode ser a melhor esquina de Pueblo Sepultura. Esse pedaço de azul inrriba da serra, já é o Brasil. Daqui, posso estar em meus dois ninhos. Tenho os pés na terra do meu país, mas meus olhos estão no céu do meu outro país.

Pra esse lado fica o aeroporto que nunca inauguraram. Avião? De vez em quando passa algum das arrozeira, só pra riscar o céu. Em Pueblo Sepultura não temos costume de avião. Repare bem: dali da Ofelia pra lá, passando pela Mildre, até chegar na praça, toda esta gente nunca subimos num Avião. Pra gente, avião é uma palavra que anda pelo ar, um dedo apontando pra cima.

Você deve ter crescido dentro dum avião? Eu sabia! Gente de fora, sempre tem mais afora que a gente.

Sentar no solzinho desta esquina tem algum parecido com o resucitamiento. Eu, depois disso, quase que não preciso mais nada. As vêis sonho com bitume, para que as tumba num se encham, de poeira. Já fizemo de tudo, ponhamo cortina de fita, tampemo as janela, mais a poeira é mais poderosa que o nosso espanar, e segue encardindo a foto.

Tem gente que diz que neste povoado, tamo cerca do céu porque aí logo começam as serra. Nasce a lâmina. A terra estanca como que procurando algo esquecido atrás das nuve. Cemitério de casas levantando os braço pra Deus.

Outros dizem que isto foi um castigo, que tamo na boca dos inferno, justinho inrriba do calor que derrete a alma. Desculpe a minha palavra entrecortada. Aqui, falamo assim porque nascemos na fronteira dos idioma. Se há algo que você não entende, é só perguntar.

\footnotetext{
Texto traduzido George Hamilton Pellegrini Ferreira, doutor em Comunicação - Universidad de Sevilla (2019). Atualmente é professor assistente da Universidade Federal do Pará.
}

Revista Moara, n. 56, vol. 2, ago-dez 2020 ISSN:0104-0944 
Em Puebla Sepultura, as pergunta faz a gente ressuscitar.

-.-.-.-.-.

Você veio procurando uma voz. Precisa de respostas que expliquem pruquê que tudo tem sido assim, pruquê a vida, as vêis, se iscapa pela porta dos fundo. «Vá em Sepultura, encontrar a voz da tua ausência.» Isso devem ter dito a você.

Que sorte que pode vir! As vêis a pessoa planifica e sempre deixa pra depois. E no ano que vem sempre é o ano que vem.

Por fim!

Você tá aqui, procurando. Viu que todos andemo tentando? Atrás de alguma cortina deve ter um ouvido que iscuita o que lhe iam dizer, mas não lhe disseram . Neste povoado sobra o palavrório. Uma letra ao lado de outra. Um silêncio e um som. As palavra são o fio que costura as nossas vida.

Tem que ter a pele bem costurada pra ouvir a voz e não indoidecer. Ninguém pediu pra escutar mas as palavra entram na noite, sacodem as cortina e falam.É de arrepiar! A pessoa se acostuma. Eu conheci munthos que não guentaron. Foram no hospital, na mãe Renata, em dona Sida... procuravam tratamento pra desenloquecer, tampa-ouvido. Tempo perdido.

Outros, nunca se deram conta. «Besteira», pensaram. «Tolice», disseram. «Essas voiz devem ser o rumor dos móveis quando a casa dormece».

A pessoa nunca sabe se é escutador. As voiz chegam e alguns intendem. O resto é o resto. A morte é isso que você não vê.

Você também se pergunta como tinha sido a vida antes de abrir os olho? Eu, sempre... Como viviam os vizinho desta rua? De que maneira cruzavam a esquina? Dizem que na iscola ensinam todas as história, mais não sei se é a mesma coisa. E os que nunca chegamo na iscola? Os meus vizinho, vão aparecê nos livro?

Eu me interto nos ontem dessas vereda.

A única forma de saber como o mundo era, é preguntando para os mais velho. Não é? 
Há que procurar um avô, se parar infrente. Se embebedar do seu memorial. Se não é assim, como é então?

Ah... mas veio a época da sombra e do sangue... Arrancaram quase todos os nossos avô. Levaram eles antes que a gente começasse a preguntar . Quiseram desavozar a gente para que nóis não encontrasse o sinal de para onde a gente tínha que ir.

O únicos avô que ficaro com vida foram os que se iscondero ditráis das cortina do medo. Aí estão, se enrrugando de tanto não fazer. Olhe a Mildre, o Renán... a maioria dos deste quarteirão... Sofrer toda uma vida pra terminar sentado diante de um cão, atirando miolo pras pomba ou metendo seus olho na monotonia, como eu.

A Valem se levanta, todos os dia, às seis da manhã. Molha a planta. Varre a vereda. E depois, se senta pra respirar o resto do ar que lhe restou. E assim sempre. Um dia e outro. Pode? Serve? Imagine todo o que a Valem deve ter vivido pra terminar sendo uma cadeira que toma chimarrão na vereda.

Mas um dia, eu não quis ser um vaso que não serve pra dar verde, e comecei a falar o tempo todo. Nunca perco a oportunidade. Pessoa que se cruza adiante, pessoa que converso. Você me vê murcho neste canto, mas é só me atiçar e eu já saio repartindo história pra todo o lado.

Ah... os jovem... têm a orelha entupidas de deslembramento. Não podem escutar esta voz de velho que sobreviveu aos tropeços. Alguns? Sim, tem razão... Você tá aqui, escutando.

Minha fia, no dia que eu já não preste pra respirar entre as gente, nesse dia junto meus treco, cruzo a estrada e me deito na terra do cemitério, conversar com os meu. Ou eu já tô aqui? Responda, minha fia. Estou vivo?

Envelhecer é se encher de palavra.

A cada dia que um passou ao lado de alguém, a cada história que um contou, a cada som que um fez aparecer... a cada-cada que um fez, tem o perfume de uma palavra que nos faz voltar, como quando um escuta uma canção e em seguida se alembra do momento onde estava quando a escutou pela primeira vez.

E me diz, a pessoa envelhece, e daí? Que vai fazer com a música que escutou? Não vai cantar elas para ninguém? Vai se enterrar junto com o som?

Revista Moara, n. 56, vol. 2, ago-dez 2020 ISSN:0104-0944 
Ninguém deveria se apagar mas apaga-se. Silenciação. Como Dona Cora que durou todo o que pôde, para ao final, se transformar num silencião na vereda, com um vira-lata deitado nos pé, um cobertor de crochê nos juêi e o olho bem desperto para ver a que hora um sai e com quem um volta pras casa. Diga-me, olhe-veja: tantos dia acima desse pé para terminar sendo uma saca de osso. Pode?

Os ano, minha fia, servem pra nos encher de cor. Quantas história já lhe contaram? Quantas episódio você contou? Não se alembra? Ah, os jovem...! Sempre esquecendo de dar duas volta na chave.

Gostaria que de você tomasse a palavra e contasse os seus aborrecimentos.Ainda não? Não se anima?... Não é fácil, mas se pode... Tudo nesta vida se pode se s pessoa quiser.

Eu já lhe contei que escuto voz? Ah, sim...! Desculpe, foi por isso que veio falar comigo. É que às vezes me parece que não a vejo. Deve ser esse sol de frente que encandeia, por isso abro o olho e você desaparece.

Não estará morrida, não? Ainda bem! O seu olho se por encima da minha palavra e eu ressuscito.

Ser velho é não encontrar uma paisagem.

Um se escora nesta coluna. Não. Não é aqui. Se senta embaixo do álamo. Também não. Vai na praça. Muito ruído. Vai na rota. Muitas novidade. Ao final, o nossos osso são o único local onde encontramos sussego. Envelhecer é não sair nunca do seu próprio esqueleto.

O peso do pó me amargura. Me atola . Me custa. Quem pode com toda a cinza do mundo? Quem vai vir escavar quando eu já não seja? O meu filho? A Tere? Algum vizinho? Niguém?

A gente que nos quer é a que desenterra o nosso silêncio. A morte é não ter palavra pra 
compartilhar.

Você queria saber como tinha sido e eu não sei como começar a contar. É mais o que eu não conto, que o que conto. É que um tem menos palavra na boca que na cabeça. Ademais, eu só vivi uma vida. Não sei como se conta o resto do mundo. Como se conta de adentro do olho do Renan ou da Ofélia ou da Tere... Se pode? Ah, que bom! Você pensa igual que eu.

As vêis, a pessoa passa muito tempo ao lado de um indivíduo, mas está distraído e não se dá conta de que semo parecido. Agora que faz várias palavras que estamo junto, eu olho a sua mão, a sua sobrancelha, a forma da sua cara, e me parece que sempre estivemos, desde antesmente, como se a gente fosse da mesma família. Um momentinho, um bate papo, um se parar, e a pessoa se reconhece. Pronto.

Em Pueblo Sepultura, quando as voz podem se desenterrar, fincar a sua unha no céu e sair, vivem pra sempre. As palavra nunca morrem se encontran uma boca e uma orelha que as façam respirar.

Você tem uma filha, vá e conte os seus ontem pra ela. Aí, você não morre nunca.

Alguns dizem que o saber não serve pra nada, que é melhor não saber. Pra que vão querer entender como a gente vivia? Se o destino tá marcado, se sempre o rio vai desaparecer, se a iscola vai esmagar a a gente, se o dono das fábrica vão fazer um buraco no muro e vão cruzar e ser feliz em Soledade. Se sempre tudo vai ser do jeito que tem sido.

Se eu fosse presidente, fazia uma lei pra que em cada porta, se pendurasse o ano de construção da cada casa. E também, que tivesse um caderno, como o que tem você, pendurado num prego da cozinha, onde se fosse anotando o nome dos que viveram ali, como foi a sua vida, qual é o registro que não fecha bem, onde estão as humidade e as goteira, qual é o vizinho que tem um cão que não deixa cochilar... Ao final, isso não custa nada e pode ajudar.

Revista Moara, n. 56, vol. 2, ago-dez 2020 ISSN:0104-0944 
Ah, se eu fosse...! Mas nunca fui. Eu sou pobre, minha fia. Quando você vai ver um pobre ser presidente? As vêis, algum que era pobre chega, mas quando presidenciam, já faz séculos que se esqueceu do que era tomar café com farinha ou polenta com leite ou mungunzá.

Pueblo Sepultura é onde os presidente não nascem.

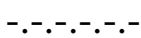

O meu filho? Uma sombrinha que faz bem. Você não perdeu um filho? Graças a Deus! Eu não posso dizer o que se sente. Essa coisa a pessoa não sabe contar. Você entra no seu quarto e a sua caminhada está vazia. Se Levanta de madrugada para ir no banheiro, e a cada vez que passa pela porta do seu quarto, sente que ele tá ali, durmindo. Já se vai levantar. E as vêiz que a pessoa se deita na cama dele e afunda o nariz nos lençol, procurando um resto de perfume. Algo. Mas nada.

Eu sempre escuto ele. Converso com ele. Toñito anda na volta e me diz: «Tudo bem, papai. Deixa de procurar. Eu estou cá, contigo, dentro de você.»

A morte é muito pouca coisa pra separar a gente das pessoa que a gente ama. A morte é um dia, o amor é todos o dia.

Aproveite para respirar a sua filha. Mergulhe o seu nariz no cabelo dela. Repasse o desenho de suas mão, brinque com seus dedo, deite os ouvido no tambor do peito dela. Vá e faça! Não use tempo em besteiras. Deixe a cama desarrumada, não lave os prato nem saia a prova outro anel... Tudo é descaminho. Vá memorizar a sua filha. Aprenda todas os seus miudezas. Olhe que depois não existe depois.

A esta hora, na sua cidade, o povo deve estar acordado, formigando ruas, aturdindo, fazendo compra, arrumando algo. Mas aqui, olhe a hora que é e onde está o povo. Em que tumba, em que sofá, em que sombra...

Talvez a minha conversa não valha a pena. Você deve estar perdendo o tempo que poderia usar em outros remédio. Quem sabe a minha palavra não sejam as que possam ajudar a encontrar as peça que faltam na sua história. Pode ser que eu não seja o último velho que sobrou...

Desculpa, as vêis falo mais do que faço. Por isso o meu povo desapareceu. Porque tinha a boca maior que a sua mão.

Revista Moara, n. 56, vol. 2, ago-dez 2020 ISSN:0104-0944 
O meu vizinho, a Tere, o meu filho, eu... Todos. Vidas de história pra terminar enterrados ao outro lado da rota, abaixo de uma cruz.

Mas gosto de acreditar que tô de volta. Toque minhas letra, veja que são de verdade . Nasceram comigo nesta esquina que olha dois país. Será que a minha sombra anda procurando um ouvido onde se encostar?

Eu queria que a palavra rio mantivesse a água da minha boca. Queria encontrar cada som que nasceu pra trovoar ao lado de outro. Descobrir a cor do entardecer, essa indecisão. Desenhar as melodia. O redondo do o. Essa surpresa! O escuro da boca. O suspiro da noite. Queria compartilhar o meu nome pra não morrer de tristeza.

Você também quer ressuscitar? Sim? Conte a sua vida para a sua filha. Sente ela na saia dos anoitecer. Achegue o seu lábio no ouvido dos seus dia, comece a soar. Como se faz? Ah... minha fia, o mistério da vida. Ninguém sabe como se começa. Eu acho que tudo se abre com uma palavra, sempre é uma palavra. Tudo se prende com umas letra que soam. Um a, um ele, um a... um ar que sai de dentro da gente e assopra na vida de outro. Tudo nasce com uma melodia. O riso e os choro, a noite e o dia, começam a soar e a pessoa brota de novo.

-.-.-.-.--.-

Quantas palavra você tem? Quantas aprendeu em todos estes ano? O que vocês vai fazer com elas? Entregue para a sua filha, para um vizinho, para alguém. Elas não nasceram para morrer na pessoa. São como a água, tem que deixar elas correr, que não façam o que fizeram com o Yaguareim. Esconderam ele dentro daquela chaminé cinza, e agora, ninguém se lembra do sabor dá água. Ninguém recorda as canoa nos balançando de um lado para o outro. Era lindo ver os areeiros cavando a água e escutar o verão do menino aprendendo a nadar.

As palavra são o rio da minha vida. As minhas companheira. Andam por mim igual que quando o Yaguareim escorregava pelas serra. Me diluviam.

Revista Moara, n. 56, vol. 2, ago-dez 2020 ISSN:0104-0944 
Um avô me contou a construção da igreja. Tinha um fazendeiro que não queria que a gente fosse tudo pecador e mandou levantar a capela, quando ainda éramos um punhado de ranchos de lata. A Tere dizia: «Temos Deus, mas não temos nem para comer».

Outro avô me disse: «Os primeiro que cheguemo nesta terra fomos os pobre. Este local é dos pobre. Procuremo uma clareira cerca do rio, fincamo as estaca, começemo a pescar e lavá a roupa na água que ainda nem tinha nome. Depois o Brasil viu que a gente tava bem perto dos seus pobre, e armou um quartel do outro lado do rio para marcá a fronteira... E assim, em um dia depois de outro, se fez a história.»

Um dia depois do outro! Nos ano que tiveram que passar para que você chegue nesta esquina, perguntando pelo seu avô, o seu Yoni, o homem que pintou as parede deste povoado, o que estava contra a iscola, o que desapareceu numa noite... O Yoni, a sua voz não aparece por nenhum lado. A sua morte tem a boca tampada.

A única forma de saber sobre o seu avô, sobre como brotou este povoado, é que eu lhe conte, se não, você não tem onde saber, porque estes povoado não aparecem em livro. Se você quer saber como se vivia nesta esquina, onde vai procurar essa informação? Por isso eu lhe conto. A gente veio ao mundo para contar. Um velho que transmite para um jovem, um amanhecer depois da noite, se não é assim, como?

Como lembram em outro povo? Como será na sua cidade? Acho que já lhe contei que cá, a gente vive como se nada tivesse acontecido, como se o mundo começasse hoje. Ninguém diz nada do Yaguareim e a sua memória de cicatriz. Ninguém fala do muro que nos deixou fora do mundo. Ninguém se lembra da chegada da iscola e a silenciação.

Será que ninguém nada nunca, também no outros cantos desta terra?

As lembrança foi feita para usar. Não pode deixar jogada no quintal, porque se apodrecem. viram pó, ar, nada. Depois, essa lembrança, já não existe, como um pedaço de vida que a pessoa não viveu.

Por isso, em Povo Sepultura, a gente vive como se a guerra tivesse terminado.

Revista Moara, n. 56, vol. 2, ago-dez 2020 ISSN:0104-0944 